\title{
Результати застосування відеоторакоскопіі для діагностики етіології синдрому легеневої дисемінації
}

\author{
М. С. Опанасенко, Б. М. Конік, О. К. Обремська, О. В. Терешкович, О. Е. Кшановський, \\ В. І. Лисенко, І. В. Ліскіна, Л. М. Загаба \\ Національний інститут фтизіатрії і пульмонології імені Ф. Г. Яновського НАМН України, м. Київ

\section{Results of application of videothoracoscopy for diagnosis of etiology of the pulmonary dissemination syndrome}

\author{
M. S. Opanasenko, B. M. Konik, O. K. Obremska, O. V. Tereshkovych, O. E. Kshanovskyi, \\ V. I. Lysenko, I. V. Liskina, L. M. Zagaba \\ Yanovskyi National Institute of Phthisiatry and Pulmonology, Kyiv
}

\section{Реферат}

Мета. Визначити чутливість, специфічність і точність відеоторакоскопічної (ВТС) і відеоасистованої торакоскопічної (BATC) біопсії легені у хворих із синдромом легеневої дисемінації (СЛД) неясного генезу.

Матеріали і методи. Проаналізовано і узагальнено дані 143 хворих із СЛД різної етіології, яким виконували ВТС або ВАТС біопсію легені. Проводили цитологічне, бактеріологічне і патогістологічне дослідження всіх отриманих біоптатів. Результати. Чутливість, специфічність і точність ВТС і ВАТС біопсії легені при СЛД є високими і суттєво не відрізняються: 98,0, 99,0 та 95,2\% і 94,7, 100,0 та 94,7\% відповідно.

Для ВТС і ВАТС біопсії легені характерні низька частота післяопераційних ускладнень - 4,8 та 7,9\% відповідно, невеликий об’єм середньої інтраопераційної крововтрати - $(20,0 \pm 3,5)$ та $(35,6 \pm 4,3)$ мл відповідно, невелика середня тривалість оперативного втручання - $(25,2 \pm 2,6)$ та $(45,1 \pm 5,6)$ хв відповідно. Частота інтраопераційних ускладнень ВТС біопсії легені становила 1,9\%. Інтраопераційних ускладнень ВАТС біопсії легені не зафіксували.

Висновки. Використання відеоторакоскопічних методик при СЛД дає можливість швидко та малотравматично встановити етіологію захворювання.

Ключові слова: відеоторакоскопія; легенева дисемінація; біопсія.

\section{Abstract}

Objective. To determine the sensitivity, specificity and precision of the videothoracoscopic (VTS) and video-assisted thoracoscopic (VATS) pulmonary biopsy in patients with pulmonary dissemination syndrome (PDS) of a vague genesis.

Materials and methods. The data, concerning 143 patients with PDS of various etiology, to whom VTS or VATS pulmonary biopsy were performed, are analyzed and summarized. Cytological, bacteriological and pathohistological investigations of all biopsies obtained were conducted.

Results. Sensitivity, specificity and precision of the VTS and VATS pulmonary biopsy in PDS are high and do not differ essentially: 98.0, 99.0 and $95.2 \%$ and $94.7,100.0$ and $94.7 \%$ accordingly.

For the VTS and VATS pulmonary biopsy a low rate of postoperative complications -4.8 and $7.9 \%$ accordingly, a moderate volume of the intraoperative blood loss $-(20.0 \pm 3.5)$ and $(35.6 \pm 4.3) \mathrm{ml}$ accordingly, moderate average duration of operative intervention $-(25.2 \pm 2.6)$ and $(45.1 \pm 5.6)$ min accordingly were characteristic. The intraoperative complications rate of the VTS pulmonary biopsy have constituted $1.9 \%$. Intraoperative complications of the VATS pulmonary biopsy were absent.

Conclusion. Application of videothoracoscopic procedures in PDS gives possibility to establish the disease etiology rapidly and miniinvasively.

Keywords: videothoracoscopy; pulmonary dissemination; biopsy.

Терміном «синдром легеневої дисемінації (СЛД) позначають групу захворювань легень невстановленої етіології, що відрізняються одне від одного патоморфологічним типом неінфекційного запалення і фіброзу переважно в інтерстиції легені, а також варіантами клінічного перебігу та прогнозу від гострого з летальним наслідком, хронічного з формуванням "стільникової легені" і прогресуючою легеневою недостатністю до сприятливого аж до клінічного вилікування [1]

На основі власних спостережень ми можемо стверджувати, що в Україні непоодиноким хворим з СЛД призначають так зване пробне лікування і лише після тривалої неефективної терапії і погіршення клініко-рентгенологічних і лабораторних показників розглядають питання виконання хворому біопсії легені $[2,3]$. Консервативна терапія без морфологічної верифікації діагнозу хворим 3 СЛД може призвести до прогресування захворювання, зумовленого як фактором часу, так і побічною дією фармакологічних препаратів. Наприклад, призначення хворому з туберкульозом легень гідрокортикостероїдних препаратів, які, зокрема, використовують для лікування саркоїдозу, може спричинити швидке прогресування захворювання $[1,2]$. Призначення глюкокортикостероїдів може викликати прогресування багатьох лімфопроліферативних захворювань. Тому в умовах запланованого впровадження страхової медицини та європейських стандартів лікування дедалі більш актуальними стають принципи доказової медицини, що декларують точне встанов- 
лення діагнозу як обов'язкової умови ефективного і якісного лікування $[4,5]$.

Проблема діагностики етіології СЛД залишається значущою для фахівців, що займаються даною патологією. Під час первинного звернення до лікаря пацієнтам з СЛд помилково діагностують хронічну обструктивну хворобу легенів, бронхіт, емфізему, бронхіальну астму, хвороби серця або інші поширені захворювання з аналогічними симптомами $[3,5,6]$.

Основою встановлення етіології при Слд є біопсія легені з патогістологічним дослідженням отриманих біоптатів. У наш час широкого розповсюдження набула методика ВТС втручання для діагностики СЛД. Можливий варіант «чистої» ВТС біопсії легені, коли операцію виконують лише через торакопорти, і ВАТС, що передбачає виконання мініторакотомії з відеопідтримкою. Загалом методи відеоторакоскопії набувають широкого розповсюдження серед торакальних хірургів з огляду на їх невеликий травматизм і мінімальний косметичний дефект $[2,6]$. Лише вивчення чутливості, специфічності і точності методик забору біопсійного матеріалу дасть можливість достовірно визначити необхідність використання інвазивних діагностичних методик при СЛД [3, 4].

Мета дослідження: визначення чутливості, специфічності і точності ВТС і ВАТС біопсії легені при СЛД неясного генезу.

\section{Матеріали і методи дослідження}

Проаналізовані і узагальнені дані 143 хворих з СЛД різної етіології. Критерієм включення пацієнтів у дослідження було виконання їм ВТС або ВАТС біопсії легені з наступним цитологічним, бактеріологічним і патогістологічним дослідженнями отриманих біоптатів. Всім паціентам проведено обстеження та лікування у відділенні торакальної хірургії і інвазивних методів діагностики Інституту в 2013 - 2017 рр. Біопсію легені виконували на базі хірургічних відділень Інституту.

Досліджуваних пацієнтів умовно розподілили на дві клінічні групи в залежності від способу забору біопсійного матеріалу: 1-ша група - 105 (73,4\%) хворих з СЛД, яким виконали ВТС біопсію легені; 2-га група - 38 (26,6\%) хворих з СЛД, яким виконали ВАТС біопсію легені.

Усім досліджуваним пацієнтам проводили загальноклінічні, інструментальні, рентгенологічні методи дослідження, а також цитологічне, бактеріологічне і гістологічне дослідження біоптатів легені. СЛД діагностовано майже в однакової кількості жінок та чоловіків.
Біопсію легені виконували пацієнтам переважно працездатного віку. Середній вік жінок у 2-й групі перевищував 50 років, що можна пояснити дисгормональними порушеннями, які виникають в клімактеричний період і супроводжуються різним ступенем ожиріння, що у свою чергу інколи значно утруднює виконання ВТС біопсії легені, тому у таких пацієнток частіше виникає необхідність виконання мініторакотомії для біопсії легені.

Розподіл пацієнтів за супутньою патологією в обох групах був приблизно однаковим (див. таблищю). Виконання 2 (1,9\%) хворим з цукровим діабетом і 4 (3,8\%) - з ВІЛ/ СНІДом ВТС біопсії легені вмотивоване меншим травматизмом даної операції в порівнянні з ВАТС біопсією легені. У згаданих пацієнтів достатньо знижені репаративні можливості, а наявність ще й патології легенів значно погіршує післяопераційний прогноз, тому, вибираючи метод біопсії легені у таких пацієнтів, перевагу надавали менш травматичній операціі.

\section{Результати}

Для визначення ефективності відеоторакоскопії для діагностики етіології СлД вивчали такі показники: чутливість, діагностична цінність і результативність методу, інтра- і післяопераційні ускладнення, середня тривалість операції, середній об'єм інтраопераційної крововтрати і тривалість післяопераційного періоду.

ВТС біопсію легені виконували за декількома методиками, розробленими на базі відділення торакальної хірургії і інвазивних методів діагностики Інституту, зокрема, вводили в плевральну порожнину через розширений торакопорт зшивальний апарат УС-30, за допомогою якого здійснювали кураєву резекцію ураженої ділянки легені. Для даної методики характерна невелика вартість, ії використовували при дрібновогнищевій дисемінації без злукового процесу в плевральній порожнині у хворих астенічної або нормостенічної тілобудови. Інший спосіб ВТС біопсії передбачав витягування назовні через торакопорт маргінальної ділянки легені і виконання кураєвої резекції за допомогою зшивального апарата УС-30. Дану методику частіше використовували у астенічних пацієнтів при локалізації вогнищ дисемінації в кортикальних шарах легені. При легеневій дисемінації зливного характеру, коли не було можливості накласти зшивальний апарат без попадання його на патологічні вогнища, ВТС біопсію легені виконували, висікаючи частину легені з наступним накладанням інтракорпорального шва. Загалом

\begin{tabular}{|c|c|c|c|c|}
\hline \multicolumn{5}{|l|}{ Розподіл хворих у групах за супутньою патологією } \\
\hline \multirow{3}{*}{ Супутня патологія } & \multicolumn{4}{|c|}{ Група хворих } \\
\hline & \multicolumn{2}{|c|}{ 1-ша $(n=105)$} & \multicolumn{2}{|c|}{2 -га $(n=38)$} \\
\hline & абс. & $\%$ & абс. & $\%$ \\
\hline Цукровий діабет & 2 & 1,9 & - & - \\
\hline Кардіогенні захворювання & 1 & 1,0 & - & - \\
\hline ВІЛ/СНІД & 4 & 3,8 & 1 & 2,6 \\
\hline Виразкова хвороба шлунка або дванадцятипалої кишки & 1 & 1,0 & - & - \\
\hline Ожиріння & - & - & 3 & 7,9 \\
\hline Хронічне обструктивне захворювання легенів & 1 & 1,0 & - & - \\
\hline Всього ... & 9 & 8,6 & 4 & 10,5 \\
\hline
\end{tabular}


дана методика низьковартісна і нескладна у виконанні. Інтраопераційні ускладнення ВТС біопсії легені діагностували у 2 (1,9\%) пацієнтів: пошкодження кортикального відділу легені під час встановлення першого торакопорту. Надриви паренхіми легені були лінійними (довжиною до 1 cм), на аеростаз суттєво не впливали, ї ліквідували шляхом використання діатермокоагуляції. Інтраопераційних ускладнень ВАТС біопсії легені не зафіксували, оскільки візуалізація операційного поля через мініторакотомний доступ більш задовільна. Післяопераційні ускладнення виникли у 5 (4,8\%) пацієнтів 1-ї групи. Із них інфікування 3 нагноєнням місць установлення торакопортів діагностовано у 2 (1,9\%). Причиною даного ускладнення можна вважати тривалу ішемізацію країв операційної рани через компресію на неї стінки торакопорта. У лікуванні хворих з інфікованими післяопераційними ранами дотримувались загальних принципів гнійної хірургії. Ще у 2 (1,9\%) пацієнтів в післяопераційному періоді спостерігали тривале недорозправлення легені на стороні операції, що потребувало використання активної аспірації до 10 діб і введення в плевральну порожнину склерозуючих засобів (стрептоміцин, аугментин, димексид тощо). У обох хворих ускладнення вилікували консервативно. У 1 (1,0\%) хворого після ВТС біопсії легені відбулось блискавичне прогресування основного захворювання (за результатами патогістологічного дослідження встановлено діагноз інвазивного аспергільозу), що призвело до смерті. Необхідно зазначити, що хворий тривалий час страждав на первинний імунодефіцит.

У 3 (7,9\%) пацієнтів 2-ї групи в післяопераційному періоді діагностували тривале недорозправлення легені. У 1 хворого виникла необхідність виконання повторної ВАТС біопсії легені з адекватним дренуванням плевральної порожнини. Після операції легеня розправилась на першу добу, а дренажі видалили через 1 тиждень. Загалом при подібних післяопераційних ускладненнях застосовували тривалу активну аспірацію і введення в плевральну порожнину склерозуючих засобів.

Середній об'єм інтраопераційної крововтрати у $1-и ̆$ групі хворих становив $(20,0 \pm 3,5)$ мл, у 2-й - $(35,6 \pm 4,3)$ мл, різниця між показниками статистично значуща (p < 0,05); середня тривалість операції - $(25,2 \pm 2,6)$ та $(45,1 \pm$ 5,6) хв відповідно ( $<0,05)$; середні строки післяопераційного стаціонарного лікування - $(6,3 \pm 1,3)$ та $(12,5 \pm$ 2,4) дня відповідно ( $<$ 0,01).

Результати досліджень дають підстави зробити висновок, що обидві методики біопсії легені за об'ємом інтраопераційної крововтрати і тривалістю операції є мініінвазивними оперативними втручаннями. Вдвічі довший термін стаціонарного лікування після ВАТС біопсії легені зумовлений лише більш тривалим заживленням мініторакотомного доступу.

Визначивши чутливість, специфічність і точність ВТС і ВАТС біопсії легені при СЛД, ми отримали такі дані: 98,0, 99,0 та 95,2\% і 94,7, 100,0 та 94,7\% відповідно.

\section{Обговорення}

Дані щодо інформативності, строків госпіталізації, частоти ускладнень, 30-добової летальності після хірургіч- ної біопсії легені, виконаної пацієнтам з СлД, опублікували V. Blackhall і співавтори (Departmen of Thoracic Surgery, Golden Jubilee National Hospital, Glasgow, UK). Середній вік пацієнтів становив 58 років, середня тривалість госпіталізації - 4 доби. У 78,6\% пацієнтів виконана ВАТС біопсія легені, у 21,4\% - відкрита біопсія легені (ВБЛ). У 51,4\% пацієнтів не збіглися клінічний і патогістологічний діагнози. Зміни в попереднє лікування внесені 45,6\% хворим. Розбіжностей в інформативності ВАТС біопсії і ВБЛ не виявлено.

J. Fibla і співавтори повідомили про результати 224 ВАТC біопсій легенів, виконаних у 13 спеціалізованих центрах Іспанії. Всі пацієнти не мали специфічного діагнозу, причому на передопераційному етапі у 49,1\% 3 них була виконана трансбронхіальна біопсія легені. Інформативність ВАТС біопсії легені в цьому дослідженні становила 87\%.

Чітка кореляція між тяжкістю передопераційного стану хворих і частотою післяопераційних ускладнень простежена О. М. Kayatta і співавторами, які дослідили результати ВАТС біопсії легені у 196 пацієнтів з СЛД за період 3 2003 по 2012 р. Точний діагноз після ВАТС біопсії легені встановлено у 88,6\% хворих. У 98,5\% хворих у передопераційному періоді виконана комп'ютерна томографія високого вирішення легенів, за даними якої тільки у 15\% пацієнтів встановили правильний діагноз і у третини як можливий. У зв'язку з цим автори зазначили, що ВАТС біопсія легені є високоінформативним методом діагностики СлД і ризик післяопераційної смертності можливо звести до мінімуму, враховуючи критерії вибору пацієнтів для операції (вік, періопераційна залежність від кисню).

\section{Висновки}

1. За допомогою відеоторакоскопічних методик при СЛД можливо швидко і малотравматично встановити етіологію захворювання.

2. Діагностична чутливість, специфічність і точність відеоторакоскопічних методик достатньо високі, що дає підстави пропонувати ці методики для широкого практичного застосування.

3. Розробка нових методів відеоторакоскопічних втручань при СЛД є актуальною в торакальній хірургіï.

\section{References}

1. Havrysiuk VK. Redkye ynterstytsyalnye zabolevanyia lehkykh. Kyiv: Veles; 2012. $148 \mathrm{~s}$.

2. Ylkovych MM. Dyssemynyrovannye zabolevanyia lehkykh. Kyiv: HEOTAR. Medya; 2011. $480 \mathrm{~s}$.

3. Szafrański W. Interstitial lung diseases among patients hospitalized in the Department of Respiratory Medicine in Radom District Hospital during the years 2000-2009. Pneumonol. Alergol. Pol. 2012;80(6):523-32.

4. Vancheri C, Failla M, Crimi N, Raghu G. Idiopathic pulmonary fibrosis: a disease with similarities and links to cancer biology. Eur Respir J. 2010 Mar;35(3):496-504. doi: 10.1183/09031936.00077309.

5. American Thoracic Society / European Respiratory Society international multidisciplinary consensus classification of the idiopathic interstitial pneumonias. Am J Respir Crit Care Med. 2002;166(3):277-304.

6. Travis WD, Costabel U, Hansell DM, King TE Jr, Lynch DA, Nicholson AG, et al. An official American Thoracic Society / European Respiratory Society Statement: Update of the international multidisciplinary classification of the idiopathic interstitial pneumonias. Am J Respir Crit Care Med. 2013;188(6):73. doi: 10.1164/rccm.201308-1483ST. 